\title{
Non-musical sound branding - a conceptualization and research overview
}

\author{
Nicolai Jørgensgaard Graakjær and Anders Bonde \\ Aalborg University, Aalborg, Denmark
}

Non-musical sound branding

1505

\begin{abstract}
Purpose - The purpose of this paper is to advance the understanding of sound branding by developing a new conceptual framework and providing an overview of the research literature on non-musical sound.
\end{abstract}

Design/methodology/approach - Using four mutually exclusive and collectively exhaustive types of non-musical sound, the paper assesses and synthesizes 99 significant studies across various scholarly fields.

Findings - The overview reveals two areas in which more research may be warranted, that is, non-musical atmospherics and non-musical sonic logos. Moreover, future sound-branding research should examine in further detail the potentials of developed versus annexed object sounds, and mediated versus unmediated brand sounds.

Research limitations/implications - The paper provides important insights into critical issues that suggest directions for further research on non-musical sound branding.

Practical implications - The paper identifies an unexploited terrain of possibilities for the use of sound in marketing and branding.

Originality/value - The paper identifies a subfield within sound-branding research that has received little attention despite its inevitability and potential significance.

Keywords Branding, Advertising, Non-musical, Research overview, Sound

Paper type General review

\section{Introduction}

This paper aims to advance the understanding of branding by conceptualizing and providing an overview of the research literature on non-musical sound. Sound branding here refers to the processes of producing sounds that continuously and consistently appear in relation to the use and/or promotion of brands. The first impression one gets when taking stock of research in sound branding is the scarcity of research publications. Routinely, publications welcome readers with regret about the lack of prior contributions to the field. The following list of examples is far from exhaustive but gives an impression of a tendency to bemoan the current state of affairs:

(C) Nicolai Jørgensgaard Graakjær and Anders Bonde. Published by Emerald Publishing Limited. This article is published under the Creative Commons Attribution (CC BY 4.0) licence. Anyone may reproduce, distribute, translate and create derivative works of this article (for both commercial and non-commercial purposes), subject to full attribution to the original 43 publication and authors. The

European Journal of Marketing Vol. 52 No. $7 / 8,2018$ pp. $1505-1525$ Emerald Publishing Limited Emerald Publishing Limited
0309-0566 DOI 10.1108/EJM-09-2017-0609

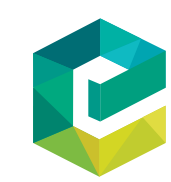

$$
\text { full terms of this licence may be seen at http://creativecommons.org/licences/by/4.0/legalcode }
$$


$\mathrm{EJM}$

$52,7 / 8$

\section{6}

Literature review reveals that, despite valuable indications for the potential of sound [...], little research is available to deepen the understanding of the auditory dimension in the identity context (Bartholmé and Melewar, 2011, p. 94).

There is a paucity of systematic research on sonic branding outcomes (Krishnan et al., 2012, p. 275).

The academic field of Sonic branding is still in its infancy and virtually non-existent within fashion retail (Alexander and Heyd, 2014, p. 267).

There are some glaring holes in our work, among them [ . . ] sonic branding (Kassabian, 2017, p. 113).

However, upon closer inspection, this first impression does not entirely hold up. Most significantly, research contributions on music are, in fact, numerous, and sound (or "sonic") branding has indeed often been characterized and exemplified almost exclusively by music. As a testimony to the field's maturation, several literature reviews exist on defined aspects and settings of music in the context of branding (Allan, 2008; Bruner, 1990; Garlin and Owen, 2006; Graakjær, 2015; Gustafsson, 2015; Herrington and Capella, 1994; Jain and Bagdare, 2011; Kellaris, 2008; Oakes, 2000, 2007; Shevy and Hung, 2013; Turley and Milliman, 2000), and for example, a large number of independent variables (including musical tempo, pitch, mode, genre, fit, familiarity and liking) have been shown to influence a wide range of dependent variables (including awareness, recall, attitudes, evaluation, behavioural intent and behaviour). Nevertheless, even if the music is removed from the equation, the following overview demonstrates that a significant body of research does, in fact, exist on non-musical sound branding. Although approximately 30 years have passed since Atwood (1989) first suggested extending imagery research to sounds in the fields of advertising psychology and consumer behaviour (Miller and Marks, 1992), there is at present no general overview of non-musical sound in the context of branding. Thus, this paper offers the first comprehensive conceptualization and overview of this research.

The exclusion of music in this context is not motivated by only the fact that literature reviews on music already exist and that contributions of non-musical sound branding seem sufficiently many, although the non-musical sound could seem to embody a narrow selection of brand stimuli. First, music in the context of branding has been significantly compromised in recent years. Conceivably, this is a reflection of music's increased prevalence, which in turn could be considered indicative of the above maturation of the field and practice. For example, music in branding contexts has been fiercely criticized "as a manifestation of instrumentally manipulated culture deployed in the service of social control" (Bradshaw and Holbrook, 2008, p. 1). Against this background, sound branding initiatives would be well advised to explore in further detail the use and potential of non-musical sounds (or even silence). Second, although all sound stimuli may be considered from the perspective of common traits or dimensions, for example, amplitude, frequency, timbre, tempo, duration, texture, spatial location and reverberation (van Leeuwen, 1999), music is special. For example, from an evolutionary viewpoint, music arguably embodies: 
Psychological and behavioural features [i.e., musical motivation, musical pulse and musical pitch] that generically distinguish it from other forms of human and animal communication, and hence, may be considered to have evolved specifically for music (Bispham, 2009, p. 41).

In addition, music can be considered particularly effective with respect to the production of connotations. For example:

One or two notes in a distinctive musical style are sufficient to target a specific social and demographic group and to associate a whole nexus of social and cultural values with a product (Cook, 1998, p. 17).

Third, although music is indeed a powerful and pervasive aspect of sound branding, as implied in the first two arguments, this focus misrepresents the reality that music is a possible but not necessary ingredient of sound branding. By comparison, non-musical sounds often appear as integral, preordained phenomena in branding settings.

\section{Research approach}

Based on the premise that the non-musical sound branding field of knowledge is currently marked by immatureness and fragmentation, this paper argues that a conceptualization and overview of the literature is the most important requirement at this stage. Accordingly, the paper does not aim to provide a meta-analysis of the effects of non-musical sound branding across the included contributions, although it does certainly highlight chosen examples of findings in this respect. Rather than a meta-analysis of effects, this paper offers a "narrative review" (Petticrew and Roberts, 2006, p. 39), synthesizing a broad range of individual contributions in various scholarly fields, such as acoustic engineering, architecture, psycholinguistics, marketing research and consumer behaviour.

The vast majority of the contributions included in this paper was found in six academic and scientific on-line databases: Academic Search Premier, SpringerLink, Emerald Insight, ProQuest, PsychInfo and Google Scholar. The following search terms were used: "sound branding", "sound brand", "sound mark", "sound logo", "sonic branding", "sonic logo", "audio branding", "audio brand", "audio logo", "acoustic branding", "akustische markenführung", "corporate sound", "product sound" AND "branding", "atmospherics" AND "sound branding" and "atmosphere" AND "sound branding". In addition, searches were performed in bibliographic databases including EThOS (British Library), DissOnline (Deutsche Nationalbibliotek), NARCIS (The Netherlands) and OAIster (University of Michigan Library). Finally, chained searches and searches via the international expert network Audio Branding Academy were conducted. To allow time to prepare the present paper, the search was terminated on August 10, 2017. At that time, the total number of contributions was 99, and they occurred in various kinds, such as theoretical surveys, theoretical case studies, content surveys, effect studies, production research, literature reviews (of more limited aspects of non-musical sound branding) and anecdotal literature.

The paper begins by introducing a typology of sounds and their connections to promoted brand objects (e.g. a product, service, place, event, person or organization). This section of the paper specifies how non-musical sound branding can be conceptualized. Subsequently, the typology serves as a framework for an overview of the existing contributions. In the final section, the paper discusses strategies for sound branding related to the issues of generic sounds and mediation. The paper concludes by suggesting directions for further research. Although the paper does not assert that the included contributions are exhaustive - let alone, of course, definitive - the following conceptualization and research overview can hopefully cater to both the not-included existing and future contributions. In 
$\mathrm{EJM}$

$52,7 / 8$

1508

Table I.

Possible

combinations of

kinds of non-musical

sound and their

connection to

brand objects addition, the paper may hopefully inspire further analysis, assessment and production of non-musical sound branding.

\section{Sounds and their connection to brand objects}

Two perspectives generally inform the typology suggested in this paper. On the one hand, as implied by the title, the typology is structured according to kinds of sounds and not, for example, by types of brands, types of mediation or setting, or differences in the contribution's disciplinary affiliation and empirical underpinning. Specifically, a widely used and accepted tripartite distinction between music, speech and other sounds (Truax, 2001; van Leeuwen, 1999) has been adopted, except for the omission of music, thus distinguishing between non-musical verbal and non-verbal sounds. Verbal sounds include the prosody of the human voice (i.e. speech intonation, speed of delivery and accent) as well as phonetic symbolism (i.e. associational meaning caused by the phonological structure and fluency). Non-verbal sounds, sometimes termed "sound effects" (Miller and Marks, 1992; Rodero et al., 2015), "auxiliary sounds" (Yorkston, 2010) or "environmental sounds" (Özcan and van Egmond, 2009; Rehan, 2016), refers to residual kinds of sound: non-verbal and nonmusical(ised) sounds that derive, or are presented as deriving, from the motion of physical objects.

On the other hand, the typology is informed by different kinds of connections between sounds and objects. While all sounds addressed in the included contributions somehow connect to an object, the connection is established and performed in two different ways. In one way, the branding process concerns sounds that connect intrinsically to the object in the sense that they embody and emanate from the object: they are sounds of the object. For example, a bottled soft drink produces sounds (e.g. clinks, pops and effervesces). Similarly, the sounds of places, such as in-store environments, derive from the object itself. In another way, the branding process focuses on sounds that are extrinsically connected to the object, most notably names, slogans and logos. Any kind of (non-musical) sound can be extrinsically connected to objects. For example, a particular quality of human voice that is used consistently to promote a soft drink in a number of commercials produces sounds that originate from "outside" the object. By existing "on behalf of" the object, that is, they are sounds for the object, they basically serve representative and authentication purposes. Hence, the two ways of connection between sounds and brands, hereafter referred to as intrinsic and extrinsic, are two categories in a dichotomous classification of brand sounds, just as verbal and non-verbal sounds represent mutually exclusive and collectively exhaustive categories (Hjelmslev, 1953[1943], p. 12) of non-musical sound.

Table I simply illustrates how the combination of general perspectives on kind of sounds and the connection between sounds and brand objects allows for four main types of nonmusical sound branding. The four main types are further specified by subcases, which provide initial impressions of the interests of the included contributions. Further refinement

\begin{tabular}{|c|c|c|}
\hline \multirow[b]{2}{*}{ Kind of sound } & \multicolumn{2}{|c|}{ Connection between sound and brand object } \\
\hline & Intrinsic & Extrinsic \\
\hline Non-verbal & $\begin{array}{l}\text { Product and packaging sounds } \\
\text { Atmospherics sounds } \\
\text { Service sounds }\end{array}$ & Sounds of (sonic) logos \\
\hline Verbal & Voice sounds of telecommunication systems & $\begin{array}{l}\text { Sounds of names } \\
\text { Sounds of slogans }\end{array}$ \\
\hline
\end{tabular}


transpires, first, through the following sections on intrinsic and extrinsic sound-brand connections, and second, during the final discussion on generic sounds and mediation.

The typology implies that the same kind of sound can be connected to brands in two different ways and, conversely, that different kinds of sound can be connected to the object in the same way. Additionally, the typology implies that not all sounds in commercial settings are connected to an object. For example, the sounds of a soft drink can appear as intrinsic when they are connected to a particular brand of a soft drink (e.g. in commercials for Coca-Cola). However, the same or similar sounds might not appear as sound brands by failing to qualify for any of the four categories when they appear, for example, as inconspicuous parts of the ambient sound in a commercial for some brand object other than bottled soft drinks. Finally, the same setting can include more than one kind of sound and function.

The framework from Table I is applied to organize the overview in two main sections devoted to intrinsic and extrinsic sound-brand connection. As a supplement and further refinement, the paper provides a web-based dynamic visualization platform (https://goo. gl/QLMXeD). When using the platform, particularities can be examined by the two filtering options "Connection between sound and brand" and "Type of research" on the right-hand side.

\section{Intrinsic sound-brand connection}

Intrinsic brand sounds are properties of the objects we perceive (Pasnau, 1999, p. 317f; see also Zampini and Spence, 2005, p. 632), that is, they originate from the objects. Although the sounds of objects have always existed, they have not always been the subject of interest in the context of branding (Carron et al., 2014, p. 2). However, a significant body of literature has emerged in recent years, and the paper has encountered 69 contributions. Most of the contributions examine non-verbal sounds, and the following overview will begin by addressing this particular kind.

A relatively large amount of research focuses on product sounds and their emotive or cognitive relevance for branding. The overall majority concentrates on intrinsic sounds of industrial products, either with the aim of theorizing about sound quality in general (Jekosch, 2004; Langeveld et al., 2013; Lyon, 2003; Raffaseder, 2007) or specifically in relation to consumers' perception of the sounds of branded products. For the latter, a considerable number of appliance sound studies have been carried out by researchers primarily in the fields of industrial design engineering and experimental psychology, reporting on empirical investigations of sound design for a wide range of electric and non-electric household products for the kitchen, for cleaning and comfort, and personal care (Fenko et al., 2010, 2011; Jansen et al., 2012; Knöferle, 2012; Knöferle et al., 2016; Ludden and Schifferstein, 2007; Ozcan and Schifferstein, 2014; Özcan and van Egmond, 2007; Özcan and van Egmond, 2009; Özcan and van Egmond, 2012; Spence and Zampini, 2007; Susini et al., 2004; van Egmond, 2008; Zampini et al., 2003). The results are multifarious and sometimes surprising. Whereas the level of fit between the sound and the visual appearance of a product may be inversely related to the degree of surprise reaction (Ludden and Schifferstein, 2007, p. 37), it appears that designed product sounds run the risk of negatively affecting the overall evaluation of pleasantness (Ozcan and Schifferstein, 2014, p. 605). Moreover, whereas expensive brands might strive for pleasant "full-bodied" product sounds, for instance, manipulating the clicking sounds of luxurious cigarette lighters (Lageat et al., 2003, p. 101) or the shutter sounds of cameras (Knöferle et al., 2016, p. 199), it has also been shown that 'high-quality' sounds for juicers, water boilers and vacuum cleaners may be associated with inexpensive brands (van Egmond, 2008, p. 5).
Non-musical sound branding

1509 
$\mathrm{EJM}$

$52,7 / 8$

1510

Other relevant appliance-sound contributions include a number of theoretical surveys and literature reviews by Spence and Zampini (2006) and Spence (2011, 2012, 2015), concentrating on appliances for food and beverage preparation. The reviews also include the sounds of food products themselves and their packagings and demonstrate that such sounds can "exert a profound, if often unacknowledged, role in our feeding behaviors, not to mention on our flavor perception" (Spence, 2012, p. 505). In fact, the synaesthesia between hearing the sounds of food (e.g. the carbonation sounds of beverages), food consumption (e.g. the crispness of cereal flakes or snacks or the creaminess of ice cream and coffee variants with milk) and food packaging (e.g. bottle and tube opening) on the one hand and smelling or tasting food on the other has been studied intensely by the same authors (Spence and Wang, 2015; Zampini and Spence, 2004, 2005). Krauss (2010) focused more exclusively on testing pouring and carbonation sounds from bottled German beers. This study found that variations in bottle design produced noticeable variations in the pouring sounds of beer flowing from the bottles. These variations, in turn, influenced test persons' associations. For example, the sound from a large and long-necked bottle produced a more powerful and rhythmic sound, which in turn reduced associations to "beruhigend" (calming) and reinforced associations to "vital" (vitality) compared to the sounds and associations connected to other bottle designs. Interestingly, perhaps as an indicator of the significance and potential of intrinsic sound branding, the study also reported, that approximately one third of the test persons believed that the quality of the pouring sound could have a direct influence on their intent to purchase a particular beer brand (pp. 54-65; see also Kilian, 2009 for an overview).

In addition, the sounds of vehicles and aircrafts have been studied extensively. Whereas some studies focus on exterior sounds, including the sounds of engines (Altinsoy, 2015; de Oliveira et al., 2010; Özcan, 2014; Sapherstein, 1998; Västfjäll et al., 2002), silent electric cars (Bodden and Belschner, 2011, 2014; D'Amico and Lenzi, 2011) and car doors (Fastl, 2005; Kuwano et al., 2006), others concentrate on interior sounds, such as engine sounds heard from inside the cabin of cars (Humphreys et al., 2009, 2011; Yoon et al., 2012) and aircrafts (Västfjäll et al., 2002, 2003), indication, operational and feedback sounds (Belschner and Bodden, 2014; Haverkamp, 2007) or, more specifically, on turn-indicator sounds (Wagner and Kallus, 2015) and the sounds of in-car switch buttons (Gaspar et al., 2016). Finally, nonverbal feedback sound is also a core issue in the field of sonic interaction design of artefacts and services, being proposed theoretically by Susini et al. (2014) and applied by Erkut et al. (2015) for teaching university students. The findings are diverse and, given the highly different tasks and objectives (i.e. sound used for the purpose of notification or pleasure), it seems difficult to draw unambiguous conclusions beyond that saturated and softened service sounds (e.g. feedback sounds) and car door sounds tend to be associated with quality, while rumbling engine sounds of sporty cars and motorbikes are associated with power regardless of their unpleasantness.

Whether heard on the radio, television or Internet, product sounds are frequently mediated through advertising as a means for product or corporate branding. The contributions include examinations of, for instance, domestic appliances and exterior vehicle sounds (Fiore and Kelly, 2007; Jessen and Graakjær, 2009; Miller and Marks, 1992), chocolate-cracking and paper-rustling sounds (Esch and Roth, 2005; Esch et al., 2006), bottleopening sounds (Fiore and Kelly, 2007; Rodero et al., 2015) and frictional sounds of handling cleaning and personal-care materials (Bolshakova, 2015; Knöferle et al., 2016). The issue of mediated versus unmediated sounds is discussed further in the last section of the paper.

An intrinsic non-verbal sound-brand connection also relates to physical objects other than industrial products, for example, consumption settings such as in-store environments in which sound may be used strategically. However, within the brand-affiliated field of 
in-store atmospherics (Kotler, 1973), the issue of non-musical ambient sound seems to have gone rather unnoticed. For example, although Turley and Milliman (2000) identified sound as one of many interior atmospheric cues or variables, sound is represented exclusively by references to experimental studies of music in service spaces. The reason is that music has been by far the most common method of controlling ambient sounds in service spaces (Yorkston, 2010, p. 160). Also telling is a more recent literature review by Spence $e$ t al. (2014), who addressed audio branding as an emerging field (within atmospherics) "starting to mature" (p. 475). The authors referred to the same and newer in-store music studies while leaving the matter of non-musical atmospheric or ambient sound to cursory remarks on the practice of non-musical sound branding in the UK that has been cited anecdotally in the literature and in journalism. In other studies of sounds in food-processing and consumption environments, such as a recent experimental work by Carvalho et al. (2015), background music is compared to interior noise. Consumers' tasting of Belgian pralines in a coffee shop was accompanied by either a Brazilian Bossanova song or "the ambient soundscape of a production kitchen" (p. 5), and the results revealed that kitchen-ambiance sounds had a negative impact on the consumers' evaluations of sweetness. Similar studies of the impact of interior noise have been documented in a literature review by Spence (2014).

Noise reduction is also a concern in architecture and acoustic ecology studies encompassing aspects of "city branding", such as strategic uses of urban soundscapes (Alves et al., 2015; Rehan, 2016). The same applies to some of the interior cabin sound studies (Västfjäll et al., 2002, 2003; Yoon et al., 2012). Other environmental or atmospheric brand-sound research include an experimental study by Sayin et al. (2015) documenting a positive effect (i.e. a sense of social presence and safety, as well as satisfaction with the place and willingness to purchase) of the sound of birdsongs in public places that people otherwise tend to perceive as unsafe when they are alone, such as car parks and metro stations.

Even though non-verbal sounds seem to provide the predominant kind of intrinsic sound-brand connection, verbal sounds also might be relevant to the extent that they come to embody the brand object. For example, in a recent historical-archival study, Murray (2015) examined how the radio voice of the fictional General Mills character Betty Crocker transformed from being a spokesperson's voice to become a sound brand itself (presenting "the sound of the station") during the 1920s and 1930s (see also Shingler and Wieringa, 1998, p. 30ff, for more on verbal sounds as brands for radio programs and stations). As a more colourful example of the communicative potential of verbal sounds, Bolshakova's television-commercial and product-identification study, including a 2001-commercial for MTV Erotic, illustrated how the "imitative sounds of women's sexual behaviour" (2015, p. 77-9) proved far more identifiable with the object (MTV Erotic) than did, for example, materials-handling sounds (e.g. rubbing and creaking) with Spontex (cleaning products company) and Durex (condom manufacturer). Further examples of intrinsic sound-brand connection through verbal means are found among interactive communication products, such as voice navigation in telecommunication and GPS devices and synthesized voice-indicator and feedback systems embodied in interactive product design (Lehmann, 2008, p. 77). Long constrained by immature technologies, "[t]he "staging" of the human voice is taking on growing importance" (Westermann, 2008, p. 154), and the time is now ripe to use synthetic speech technology as an individualizing brand feature. Nevertheless, the body of branding research focusing particularly on verbal materials appears to be relatively sparse in the context of intrinsic sound-brand connection. 
$\mathrm{EJM}$

$52,7 / 8$

1512

\section{Extrinsic sound-brand connection}

Extrinsic brand sounds refer to any kind of communicative, semiotic or expressive feature (verbal or non-verbal) that helps construct and promote the distinctiveness of brand objects. The paper has encountered 30 contributions most of which focus on verbal sound-brand connections. The following overview will begin by addressing this particular kind. Generally, names and slogans, provide image and identity through either phonetic symbolism (e.g. word fluency, choices of consonants and vowels, use of alliterations) or prosody (e.g. intonation or pitch contour, stress, rhythm, speed, timbre, loudness and national or regional accent). Put simply, what matters is not only the choice of words but also how the words sound (Harris et al., 1986, p. 13f). Still, regarding phonetic symbolism (a field of psycholinguistics), the bulk of the research is based on visual cues instead of auditory cues (Luna et al., 2010, p. 860), that is, respondents are usually processing names or slogans written on a screen or on paper (see, e.g. the slogan memorability study by Reece et al., 1994). This may seem reasonable "[g]iven the heavy reliance on visuals in marketing and advertising" (Carnevale et al., 2010, p. 183). However, the relevance of testing names and slogans as spoken entities seems obvious, considering the increasing ubiquity of auditory and audio-visual platforms or touchpoints for brand exposure (e.g. television, radio, Internet, in-store environments and 3G communication devices). Besides, in an experimental study, Costley et al. (1997) used fictitious advertising slogans, either visual or auditory, as stimuli and found that their ability to evoke long-term memory depends on whether the slogans suggest "vivid imageries spontaneously" or promote "abstract claims [...] difficult to visualize" (p. 221), in addition to the sensory mode with which the slogan is presented (p. 228). To be sure, this paper contends that branding with sound and the psychophysics of its sensation must be, first and foremost, matters of auditory processing, which is why, in the following section, the paper concentrates exclusively on research contributions focusing on spoken names and slogans.

Given these premises, the amount of research interest appears to be comparably limited, and there have been found only a handful of studies using spoken words as experimental stimuli. Many of them focus on comparing the effects of visual and auditory cues. For example, Pan and Schmitt (1996) detect mutual opposition among native-English- and native-Chinese-speaking people regarding written versus spoken names, with reference to the effect on brand attitude and purchase intention (willingness to buy). The authors note that whereas native English speakers are affected primarily by the sound of the brand, native Chinese speakers are more affected by the script of the brand. Argo et al. (2010) restrict their study to native English speakers who are tested for an affective response (i.e. positive and negative valence) on the basis of fictitious names with versus without phonetic repetitions. Through six experiments, they show that the auditory processing of repetitive names elicits positive effect. Additionally, in a more recent paper, Klink and Wu (2014) test for product choice on the basis of English-speaking business students' evaluations of a number of fictitious car brand names using combined sound symbolism imbeds. Here, the authors conclude that the combination of consistent imbeds is more preferred than inconsistent imbeds.

In addition to the experimental studies of visual versus auditory processing of names, Luna et al. $(2009,2010,2013)$ studied brand evaluation and recall. On the basis of exclusively auditory stimuli, the authors investigated the relationship between spelling and pronunciation, coupled with considerations on ambiguous versus unambiguous words, nonword names versus names using existing words, and congruence versus incongruence according to product category. The results revealed that auditorily presented names with consistent sound-to-spelling correspondences (easily spelled names) enhance positive brand 
evaluations and provided a higher level of brand sound recall (see also the review by Carnevale et al., 2010).

The paper has not come across any slogan studies using auditory cues to investigate phonetic characteristics, e.g. alliterations (Kilian, 2009, p. 38). Rather, studies on slogan sounds focus on the strategic use of prosody or tone of voice. Despite its relation to "the material aspect of speech" (van Leeuwen, 1999, p. 125), prosody is not traditionally a matter of linguistics, psycholinguistics, or any other single discipline or area of expertise. As noticed by van Leeuwen:

The linguistic study of speech sound (phonology) carefully defined itself as concerned only with the form of speech sound, and as quite separate from the study of their materiality. This became a subject of a separate branch of knowledge, phonetics - and phonetics steered clear of studying sound as a semiotic system, concentrating on studying the physiology of sound production, the psychology of speech perception and the acoustics of sound (1999, p. 126).

That excludes the study of prosody, which is instead included in the interdisciplinary field of paralinguistics (Dahl, 2010, p. 169), although this hardly counts as a disciplinary field on its own. The latter is affirmed by the various academic or professional affiliations (other than linguistics) represented in the contributions, such as media communication and aesthetics, marketing psychology and consumer behaviour as well as acoustic engineering and production design.

More significantly, the contributions are generally characterized by a high level of fragmentation and discontinuity. It appears that not only disciplinary boundaries but also paradigm boundaries and language barriers function practically as "demarcation lines", dividing research communities into isolated "islands" with little or no mutual consultation. Most notably, German-language studies, which represent a significant portion of research in voice branding (as in sound branding in general), are virtually never noticed by not-native German-speaking researchers. This applies, for instance, to the systematic theorization by Lehmann $(2007,2008)$ and the smaller-scale accounts of theoretical and case perspectives by Bronner (2007), all having gone completely unnoticed in the literature reviews by Dahl (2010) and Peck and Childers (2008), whose studies concentrate exclusively on experimental investigations in the field of marketing psychology and consumer behaviour. Not even English-language surveys (Westermann, 2008) are quoted or discussed.

It seems all the more relevant to bring together the different research traditions into one presentation. In addition to the (German) theoretical and overview studies and the (NorthAmerican) reviews mentioned above, there are a number of empirical studies conducted by industrial professionals in cooperation with university scholars (Dytz et al., 2012; Tonetto and Trevisan, 2012). In one of the most extensive studies, Anzenbacher et al. (2015) presented an overview of "branch-typical psychoacoustical properties" on the basis of a spectral analysis of 200 registered sound trademarks, which are further classified according to the line of business. Among those sounds that include the human voice, the authors found speech far more common than singing, whistling, whispering, screaming and humming, especially in the case of a retail business (p. 2-3). The reason for this is, ostensibly, "[t]he strong emotional effectiveness of the voice, which, through direct interpersonal communication, also builds a close emotional relationship with the recipient as a potential customer" (p. 3). Rodero et al. (2015) have drawn similar conclusions about companies "seeking closeness with consumers" (p. 370) by the strategic use of voice (among other sound elements) in the branding of Intel, McDonald's and Coca-Cola through radio and Internet. Based on a textual examination of the importance of pitch, timbre, gender and (regional) accent, the authors show an unused potential of sound branding in radio. The same parameters have, in a number of studies, been tested experimentally relative to
Non-musical sound branding

1513 
product and brand recall, consumers' attitudes towards the advertised product or brand and their purchase intentions. It has, for instance, been demonstrated that the usage of lowerpitched voice leads to more favourable brand attitudes (Chattopadhyay et al., 2003; Peterson et al., 1995) and affects consumers to infer larger product sizes (Lowe and Haws, 2017), whereas the market potential of using time-compressed speech appears more uncertain (LaBarbera and MacLachlan, 1979; MacLachlan and Siegel, 1980; Moore et al., 1986; North et al., 2004; Schlinger et al., 1983).

The branding potential of accent has been celebrated by some sound branding professionals, such as Lafferty's (2015) anecdotal account of the powerfulness of regional accents for dental professionals handling customer phone calls and Bronner (2007, p. 87) brief exemplifications of the Swedishness, friendliness and jolliness of the voice-over in a German advertising spot for the furniture store Ikea (Kilian, 2009, p. 43; Anzenbacher, 2012, p. 112). In this context, however, it might be instructive and interesting to dig further into experimental work in that subfield and note, for inspiration, that whereas the use of nonstandard English leads to higher attention and memory, standard English leads to higher credibility and brand preference (Lalwani et al., 2005; Morales et al., 2012).

As regards non-verbal extrinsic sound-brand connections, contributions are very few. A reason for this might be that it is not self-evident that logos (i.e. one of the most recognizable assets) include non-musical sound and that these sounds should have any notable significance compared to logo graphics. However, logos can have an auditory equivalent in the form of a sonic (or audio) logo - here distinguished from musical logos (i.e. small melodic units) - for example in the form of the sound of (the opening of) a cash register to promote a chain of supermarkets. Anzenbacher (2012) presents a handful of other examples of sonic logos of automobile as well as electronics and software engineering companies, all characterized by "geräuschhaften" (noisy) sounds (pp. 98-99). Moreover, sound can be implied as a synesthetic accompaniment to visuals. Because visual means of expressions can be experienced as "noisy", "invoking" or "calling", they are possibly associated with auditory impressions - see, for instance, the discussion of synaesthesia in Cook (1998, p. 24ff), Danesi (2006, p. 71) and Haverkamp (2007).

\section{Potentials and pitfalls of non-musical sound branding - generic sounds and mediation}

From the distinction between intrinsic and extrinsic sound-brand connection it follows that the former can be considered from the perspective of generic sounds - that is, sounds that are characteristic of or relating to a class of products and not to any one product in particular. In this regard, an important matter concerns how cars and carbonated drinks have generic sounds in the form of, e.g. engine and fizzing bottle-opening sounds, respectively, and consumers are normally able to identify and differentiate those sounds. From a sound branding perspective, however, the issue is whether consumers can differentiate between and associate specific meanings to the sounds of different cars and different bottled soft drinks.

Two sound-branding strategies could be devised to meet this challenge. One strategy would focus on developing a specific, distinctive variant of (a part of) the generic sound in question, whereas another strategy would focus on "annexing" the generic sound as part of the brand in question. Although the two strategies are not mutually exclusive, they operate at different stages. The former will necessarily operate at the level of the design and production of the object. The distinctiveness of the sound must appear as a "built-in" feature, and it must be recognizable both during consumers' actual object handling or performance (termed "lived experience" in Underwood, 2003) and during consumers' 
processing of advertisements promoting (the sound of) the object (termed "mediated experience" in Underwood, 2003). Examples of the production of (and desire to legally protect) a specific variant of a generic sound include the roar of the Harley-Davidson motor (Özcan, 2014; Sapherstein, 1998), the crunch of Kellogg's cornflakes (Lindstrom, 2005, p. 16-17) and the so-called "Flensburger plop" used in advertising to promote the flip-top bottles designed by the North German brewing company (Bronner, 2007, p. 88; Kilian, 2009, p. 45; Krauss, 2010, p. 53; Anzenbacher, 2012, p. 111). Alternatively, to "annex" a generic object sound implies that promoters enforce and anchor the linkage between a sound and an

Non-musical sound branding object in consumers' memories by repeated and consistent association. This strategy operates almost exclusively at the level of promotion and advertising. Although consumers might be unable to specify the brand origin of any one fizzing bottle-opening sound - they sound practically the same across the generic category - consumers might associate the sound with Coca-Cola (and not, say, Pepsi) due to the numerous commercials over the years consistently highlighting that particular sound when promoting Coca-Cola (Bronner, 2007, p. 88) and because the Coca-Cola brand is generally recognized as larger than the Pepsi brand (Danesi, 2006, p. 15; Interbrand, 2016).

Coca-Cola's fizzing bottle-opening sound may be characterized as an icon (Bronner, 2007, p. 88; Kilian, 2009, p. 45), as its appearance is analogous to the real act of opening a carbonated beverage. However, the sound also qualifies as an index (Danesi, 2006, p. 27ff) because it appears closely and causally related to the opening of a bottle. Furthermore, the sound can be characterized as a symbol, since its conventional, commercially mediated association with various themes and lifestyles may connote change, happiness, a spark of life and an instant transformation to exquisite places (Rodero et al., 2015, p. 368; for similar processes of signification, see Esch and Roth, 2005; Esch et al., 2006). The symbolic mode requires considerable promotional and cultural processes of learning towards an agreed convention. For instance, the case of "music" exemplifies how culturally developed conventions operate to realize the evolutionary potentials through, for example, interpersonal interactions (e.g. lullabies), social events (e.g. funerals and weddings) and media texts (e.g. moving pictures and television series). Consequently, attempts to annex generic sounds in brands can, if not done correctly (e.g. consistently, thoroughly and based on tests), potentially produce unintended, detrimental effects such as consumer associations to competing brands. By comparison, the indexical mode offers a more constrained and "motivated" (Chandler, 2007, p. 38) relationship. The sound of an object is relatively confined and, hence, precise in pointing at and representing its qualities (e.g. size, shape and weight). Thus, the indexical mode arguably presents a particularly significant and accessible potential in the context of sound branding.

Following from the question of the development versus annexation of generic sounds, the paper now addresses two important implications of mediation. First, the mediation of sounds begs the question of whether some media are more suitable for (specific kinds of) sound branding than are other types. At first sight, it is, of course, relevant to observe that some media are inherently auditory (e.g. radio), whereas others are audiovisual (e.g. television and Internet). In auditory media, non-musical sound branding will tend to rely on verbal or (prior) visual affirmation. In addition to the potentials of verbal address to represent or mimic, for example, specific persons, demographics and professions (Tagg, 2013, p. 357), it seems to have particularly important and accessible potential to attract the attention of and make contact with the consumer at an emotional level. The example of the potentially symbolic effect of the bottle-opening sound of Coca-Cola illustrates in turn how a sound may, in rare circumstances, prevail as a brand due to prior visual associations, even if it is not accompanied by verbal affirmation. Notwithstanding the (emotional) potential of 
$\mathrm{EJM}$

$52,7 / 8$

1516

verbal address, verbal affirmation is not necessarily needed in audiovisual media, as various types of visual associations can be arranged and the minds of the consumers can potentially activate the sound of the brand based on the visuals alone (which would illustrate a case of synaesthesia, as discussed previously). Moreover, audiovisual media seem to differ in terms of the existence and suitability of sound in general. Based on the available scholarly studies that include large samples of web ads (Jensen and Helles, 2007; Tsang, 2007), the general impression is that web ads - including both embedded web ads and linked websites (Janoschka, 2004) - do not often include sound. There are several possible reasons for this lack of sound. Some have argued for future change, stating "we are still in the "silent" era' of the Web, but "talkies" are not far away" (Jackson and Fulberg, 2003, p. 7). However, another reason, which seems to resonate better with the continuously, relatively silent web, might be related to the medium's characteristics. Internet users compared to, e.g. television viewers, appear more likely to experience sounds in ads as an intrusive, negative element. This tendency can likely be explained by the Internet's status as a pull media, in which the user typically expects and experiences a high level of control over information (e.g. one searches the Internet).

Second, mediation raises the issue of how mediated sound corresponds to unmediated sound during a lived experience. To be sure, the mediation of sounds in advertising entails the second level of sound production, i.e. "the production of the sound of the sound" of the objects. From the production perspective, most - if not all - sounds in advertisements are sound effects in the sense that audio technology has been used to fine-tune and produce specific aspects of the object's sound. What is important, however, from a reception and brand-building perspective is not only to what extent the sound brand prevails in an auditory foreground. For example, if a brand uses a distinct car engine sound and there is background noise (city noises, other cars etc.), this noise could be detrimental or distracting to the viewer. It is also important, to what extent consumers can appreciate the sound produced during a lived experience as similar to, if not identical with, the sound encountered during the mediated experience of advertising. For example, as stated by Fiore and Kelly (2007):

While items like music DVDs and computers are easier to sell online because the presented product is very close to the actual one purchased and technical specifications can be easily communicated in a textual format, many others such as fresh foods and fabrics, bought largely according to sensory qualities, present serious difficulties for online retailers and shoppers alike (p. 602).

Some degree of discrepancy between the two types of sound distribution is unavoidable from a physical, textual perspective (i.e. regarding the "sound of the sound"). For example, different settings (e.g. indoor and outdoor) of lived experience produce dissimilar variants of the sound, and the mediated experience includes different versions of the sound depending on the (quality of the) distribution channel (e.g. radio, Internet, television). In addition, consumers are arguably inclined to accept a certain degree of discrepancy due to familiarization with conventions of mediated advertising, which imply that brand objects are typically represented as "looking (or sounding) their best" and not necessarily the way they will appear in all settings of real life. As an example from the visual domain of advertising, one might think of the often-reported discrepancy between the actual appearance of a still popular (it seems) type of burger compared with its promotional representation (Consumer Reports, 2014; Frisk, 2015). Seen as "exaggerated advertising or hyperbole", this form of promotion could perhaps be "understood as a true claim about a product that can be proven, yet is not taken seriously by the receiver of the message; therefore, it does not mislead the consumer" (Muela-Molina and Perelló-Oliver, 2013, p. 18). 
For example, the fizzing sound of opening a Coca-Cola bottle could arguably be exaggerated in a commercial without necessarily compromising consumer's evaluation of (the sound of) the product when approached in real life. Moreover, a discrepancy might be justified considering that consumers have habituated to limitations of message sound reproduction due to "low-quality PC speakers on a low bandwidth connection" (Fiore and Kelly, 2007, p. 606).

However, because consumers' perceptions, attitudes, and "what they take seriously" in relation to advertisements seem to vary significantly (as indicated by the variation of consumer responses in, Olson and Dover, 1978; Rotfeld and Rotzoll, 1980; Schutz and Casey, 1981), it is perhaps more relevant whether the advertisement has the potential or capacity to mislead (as stressed in Grunert and Dedler, 1985, p. 152). The potential for misleading or deceptive advertising has been found to exist when advertisers use cues to imply that a product possesses certain features that, in reality, it does not. For example, "special camera techniques exaggerate the appearance and performance of toy racing car sets" (Cohen, 1972, p. 14). Cohen concludes, "since magnification and diminution of stimuli can result in a misinterpretation of the judgment of magnitudes, such potential misinterpretations should be considered in the evaluation of possible deception in adverting" (Cohen, 1972, p. 14). It should be added that qualitative "beautification" of stimuli (exemplified by the aforementioned promotion of burgers) ought to supplement the focus on promotional processes of quantitative up- and downsizing. At any rate, although the definitions and typologies of misleading and deceptive advertising are numerous, they focus on visual and verbal (i.e. semantic and rhetorical) claims and not representations of sounds (Boush et al., 2009; Hastak and Mazis, 2011). It is thus unclear whether - and, if so, to what extent misleading or deceptive advertising manifests and are responded to in the context of nonmusical sound branding.

\section{Conclusion}

The paper has demonstrated that sound branding includes more than mere music. A typology of non-musical sound branding has been proposed encompassing four main types of non-musical sound branding, and significant contributions within each of the four types have been identified. The paper suggests that the typology can serve as a framework for the production, analysis and research of non-musical sound branding. Although it is well beyond the scope of this paper to systematically (e.g. meta-analytically) address the issue of the effects of non-musical sound branding, the specification of the main contributions within each category identifies where to look for specific effects. It should be added that although this paper focused on the effects of (non-musical) sound, silence - as produced by (surrounding) sounds - can also result in significant effects (Olsen, 1994, 1995, 1997). This finding indicates that the production of sound branding should not only consider the question of what kind of sound should be activated but also whether sounds are advisable at all in the given setting - a consideration mostly relevant to extrinsic sound-brand connection and mediations of intrinsic sound-brand connection.

This paper has specified a number of research areas that seem underdeveloped at the present time. First, a lacuna has been identified regarding research in the field of nonmusical atmospherics in commercial environments. Second, there has not been found any contribution that focuses specifically and exclusively on non-musical sonic logos. Third, and perhaps most significantly, there appear to be only a few comparative brand-strategy studies focusing on generic sounds, such as empirical examinations or testing of potential differences between constructed and annexing generic object sounds, or differences between perceptions of mediated and unmediated brand sounds. For the latter, it is striking that the 
vast majority of research is based on recorded sound stimuli prepared for experimental purposes and mediated electronically through headphones (Fenko et al., 2011; Ludden and Schifferstein, 2007; Ozcan and Schifferstein, 2014; Ozcan and van Egmond, 2007, 2009, 2012; van Egmond, 2008), whereas ecological studies of appliance and food sounds appear to be absent. Thus, the significance of setting is rarely recognized, which seems unfortunate for the examination of potential problems of sound discrepancies. Consequently, it is hypothesized that, unless clearly motivated by some "true disclaimer" (e.g. a dramatic or humorous effect in the advertisement), any notable difference between the lived and mediated experiences of sounds has the capacity to mislead consumers. However, further research is needed to qualify if, how, and what type and scale of discrepancies have actual effects on consumers. As already indicated, the paper suggests that the presented typology and overview of the existing contributions can serve as a backdrop against which this and additional future research initiatives within the field of non-musical sound branding can be inspired and considered.

\section{References}

Alexander, B. and Heyd, B. (2014), "Sonic branding within fashion retail brands: restrictions, opportunities, effectiveness and success", in Rajaram, N.J., Prasad, G.H.S. and Belli, S.K.M. (Eds), Contemporary Issues and Trends in Fashion, Retail and Management, BS Publications, Hyderabad, pp. 154-172.

Allan, D. (2008), "Sound retailing: a review of experimental evidence on the effects of music on shopping behavior", in Lowrey, T. (Ed.), Brick \& Mortar Shopping in the 21st Century, Lawrence Erlbaum, New York, NY, pp. 33-52.

Altinsoy, M.E. (2015), "A model for the sportiness perception of exterior vehicle engine start sounds", International Journal of Vehicle Noise and Vibration, Vol. 11 Nos 3/4, pp. 313-337.

Alves, C.M. Lopes, P.G. and Gomez, L.S.R. (2015), "City brand experience: urban trends and aesthetic experiences from the perspective of city branding", Senses \& Sensibility, available at: http:// unidcom.iade.pt/radicaldesignist/city-brand-experience/ (accessed 9 December).

Anzenbacher, C. (2012), Audiologos: integrative Gestaltungsmaßnahmen Vor Dem Hintergrund Der Musikpsychologie, Nomos, Baden-Baden.

Anzenbacher, C., Czedik-Eysenberg, I., Reuter, C. and Oehler, M. (2015), "Der klang der marken. Branchentypische psychoakustische eigenschaften von audiologos", Proceedings der 41. jahrestagung für akustik, 2015, Nuremburg, pp. 928-931.

Argo, J.J., Popa, M. and Smith, M.C. (2010), "The sound of brands", Journal of Marketing, Vol. 74 No. 4, pp. 97-109.

Atwood, A. (1989), "Extending imagery research to sounds: is a sound also worth a thousand words?", Advances in Consumer Research, Vol. 16 No. 1, pp. 587-594.

Bartholmé, R.H. and Melewar, T.C. (2011), "Exploring the auditory dimension of corporate identity management”, Marketing Intelligence \& Planning, Vol. 29 No. 2, pp. 92-107.

Belschner, T. and Bodden, M. (2014), "Comprehensive automotive active sound design part 2: operational sounds and brand sound", Proceedings of inter-noise, 2014, Melbourne, pp. 1-4.

Bispham, J.C. (2009), "Music's 'design features': musical motivation, musical pulse, and musical pitch", Musicae Scientiae, Vol. 13 No. 2, pp. 41-61.

Bodden, M. and Belschner, T. (2011), "Sound design for silent vehicles: security, identity, emotion", in Bronner, K., Hirt, R. and Ringe, C. (Eds), Audio Branding Academy Yearbook 2010/2011, Nomos, Baden-Baden, pp. 67-83.

Bodden, M. and Belschner, T. (2014), "Comprehensive automotive active sound design part 1: electric and combustion vehicles", Proceedings of Inter-noise, 2014, Melbourne, pp. 1-6. 
Bolshakova, N.F. (2015), "Sound codes in advertising”, Mediterranean Journal of Social Sciences, Vol. 6 No. 3, pp. 75-81.

Boush, D.M., Friestad, M. and Wright, P. (2009), Deception in the Marketplace: The Psychology of Deceptive Persuasion and Consumer Self-Protection, Taylor \& Francis, New York, NY.

Non-musical sound branding

Bradshaw, A. and Holbrook, M.B. (2008), "Must we have muzak wherever we go? A critical consideration of the consumer culture", Consumption Markets \& Culture, Vol. 11 No. 1, pp. 25-43.

Bronner, K. (2007), "Schöner die marken nie klingen ... jingle all the way? Grundlagen des audio-branding", in Bronner, K. and Hirt, R. (Eds), Audio-Branding. Entwicklung, Anwendung, Wirkung Akustischer Identitäten in Werbung, Medien Und Gesellschaft, Reinhard Fischer, München, pp. 82-96.

Bruner, G.C. (1990), "Music, mood, and marketing”, Journal of Marketing, Vol. 54 No. 4, pp. 94-104.

Carnevale, M., Lerman, D. and Luna, D. (2010), "Hear is the thing: auditory processing of novel nonword brand names", in Krishna, A. (Ed.), Sensory Marketing: Research on the Sensuality of Products, Taylor \& Francis, New York, NY, pp. 183-198.

Carron, M., Dubois, F., Misdariis, N., Talotte, C. and Susini, P. (2014), "Designing sound identity: providing new communication tools for building brands 'corporate sound", Proceedings of the 9th audio mostly: a conference on interaction with sound, 2014, Aalborg, p. 15.

Carvalho, F.R., van Ee, R., Rychtarikova, M., Touhafi, A., Steenhaut, K., Persoone, D. and Spence, C. (2015), "Using sound-taste correspondences to enhance the subjective value of tasting experiences", Frontiers in Psychology, Vol. 6, p. 1309.

Chandler, D. (2007), Semiotics: The Basics, Taylor \& Francis, New York, NY.

Chattopadhyay, A., Dahl, D.W., Ritchie, R.J.B. and Shahin, K.N. (2003), "Hearing voices: the impact of announcer speech characteristics on consumer response to broadcast advertising", Journal of Consumer Psychology, Vol. 13 No. 3, pp. 198-204.

Cohen, D. (1972), "Surrogate indicators and deception in advertising", Journal of Marketing, Vol. 36 No. 3, pp. 10-15.

Consumer Reports (2014), "Fast food fare isn't picture-perfect. Why fast food meals don't appear as advertised", available at: www.consumerreports.org/cro/magazine/2014/02/fast-food-not-aspictured/index.htm (accessed 9 December).

Cook, N. (1998), Analysing Musical Multimedia, Oxford University Press, Oxford.

Costley, C., Das, S. and Brucks, M. (1997), "Presentation medium and spontaneous imaging effects on consumer memory", Journal of Consumer Psychology, Vol. 6 No. 3, pp. 211-231.

D’Amico, G. and Lenzi, S. (2011), "Sound for electric vehicles”, in Bronner, K., Hirt, R. and Ringe, C. (Eds), Audio Branding Academy Yearbook 2010/2011, Nomos, Baden-Baden, pp. 85-94.

Dahl, D.W. (2010), "Understanding the role of spokesperson voice in broadcast advertising”, in Krishna, A. (Ed.), Sensory Marketing: Research on the Sensuality of Products, Routledge, New York, NY, pp. 169-182.

Danesi, M. (2006), Brands, Routledge, New York, NY.

de Oliveira, L.P.R., Stallaert, B., Janssens, K., van der Auweraer, H., Sas, P. and Desmet, W. (2010), "NEX-LMS: a novel adaptive control scheme for harmonic sound quality control", Mechanical Systems and Signal Processing, Vol. 24 No. 6, pp. 1727-1738.

Dytz, P., Lima, F. and Tonetto, L.M. (2012), "Voice and sound logo for the brand airela", in Bronner, K., Hirt, R. and Ringe, C. (Eds), Audio Branding Academy Yearbook 2011/2012, Nomos, BadenBaden, pp. 71-80.

Erkut, C., Serafin, S., Hoby, M. and Sårde, J. (2015), "Product sound design: form, function, and experience", Proceedings of the audio mostly 2015 on interaction with sound, ACM, Thessaloniki.

Esch, F.R. and Roth, S. (2005), "Der beitrag akustischer reize zur integrierten markenkommunikation", Marketing Zfp, Vol. 27 No. 4, pp. 215-236. 
$\mathrm{EJM}$

$52,7 / 8$

Esch, F.R., Roth, S. and Strödter, K. (2006), "The effect of the integration of different acoustic and visual stimuli depending on target groups involvement", in Diehl, S. and Terlutter, R. (Eds), International Advertising and Communication: Current Insights and Empirical Findings, Gabler, Wiesbaden, pp. 69-88.

Fastl, H. (2005), "Psycho-acoustics and sound quality", in Blauert, J. (Ed.), Communication Acoustics, Springer Berlin Heidelberg, Berlin, Heidelberg, pp. 139-162.

Fenko, A., Schifferstein, H.N. and Hekkert, P. (2011), "Noisy products: does appearance matter?", International Journal of Design, Vol. 5 No. 3, pp. 77-87.

Fenko, A., Schifferstein, H.N.J. and Hekkert, P. (2010), "Shifts in sensory dominance between various stages of user-product interactions", Applied Ergonomics, Vol. 41 No. 1, pp. 34-40.

Fiore, S.G. and Kelly, S. (2007), "Surveying the use of sound in online stores: practices, possibilities and pitfalls for user experience", International Journal of Retail \& Distribution Management, Vol. 35 No. 7, pp. 600-611.

Frisk, A. (2015), "Advertising vs real life: why the food we eat doesn't look like the food in the pictures", Global News, available at: http://globalnews.ca/news/2049024/advertising-vs-real-life-why-thefood-we-eat-doesnt-look-like-food-in-the-pictures/ (accessed 9 December).

Garlin, F.V. and Owen, K. (2006), "Setting the tone with the tune: a meta-analytic review of the effects of background music in retail settings", Journal of Business Research, Vol. 59 No. 6, pp. 755-764.

Gaspar, J., Fontul, M., Henriques, E., Ribeiro, A., Silva, A. and Valverde, N. (2016), "Psychoacoustics of in-car switch buttons: from feelings to engineering parameters", Applied Acoustics, Vol. 110, pp. 280-296.

Graakjær, N.J. (2015), Analyzing Music in Advertising. Television Commercials and Consumer Choice, Routledge, New York, NY.

Grunert, K.G. and Dedler, K. (1985), "Misleading advertising: in search of a measurement methodology", Journal of Public Policy \& Marketing, Vol. 4, pp. 153-165.

Gustafsson, C. (2015), "Sonic branding: a consumer-oriented literature review", Journal of Brand Management, Vol. 22 No. 1, pp. 20-37.

Harris, R.J., Sturm, R.E., Klassen, M.L. and Bechtold, J.I. (1986), "Language in advertising a psycholinguistic approach”, Current Issues and Research in Advertising, Vol. 9 Nos 1/2, pp. 1-26.

Hastak, M. and Mazis, M.B. (2011), "Deception by implication: a typology of truthful but misleading advertising and labeling claims", Journal of Public Policy \& Marketing, Vol. 30 No. 2, pp. 157-167.

Haverkamp, M. (2007), "Synästhetische aspekte der geräuschgestaltung im automobilbau", in Bronner, K. and Hirt, R. (Eds), Audio Branding. Entwicklung, Anwendung, Wirkung Akustischer Identitäten in Werbung, Medien Und Gesellschaft, Reinhard Fischer, Munich, pp. 228-244.

Herrington, J.D. and Capella, L.M. (1994), "Practical applications of music in service settings", Journal of Services Marketing, Vol. 8 No. 3, pp. 50-65.

Hjelmslev, L. (1953), Prolegomena to a Theory of Language, Waverly Press, Baltimore.

Humphreys, L., Giudice, S., Jennings, P., Cain, R., Dunne, G. and Allman-Ward, M. (2009), "Understanding the opinion forming processes of experts and customers during evaluations of automotive sounds", in Harris, D. (Ed.), EPCE 2009: Engineering Psychology and Cognitive Ergonomics, Springer Berlin Heidelberg, Berlin, Heidelberg, pp. 386-395.

Humphreys, L., Giudice, S., Jennings, P., Cain, R., Song, W. and Dunne, G. (2011), "The influence of company identity on the perception of vehicle sounds", Ergonomics, Vol. 54 No. 4, pp. 338-346.

Interbrand (2016), "Best global brands 2016 rankings", available at: http://interbrand.com/best-brands/ best-global-brands/2016/ranking/ (accessed 26 August 2017).

Jackson, D. and Fulberg, P. (2003), Sonic Branding, Palgrave, London.

Jain, R. and Bagdare, S. (2011), "Music and consumption experience: a review", International Journal of Retail \& Distribution Management, Vol. 39 No. 4, pp. 289-302. 
Janoschka, A. (2004), Web Advertising: New Forms of Communication on the Internet, John Benjamins Publishing Company, Amsterdam.

Jansen, R.J., van Egmond, R. and de Ridder, H. (2012), "Sound meets image: freedom of expression in texture description", Proceedings of SPIE (International Society for Optics and Photonics), Burlingame, CA, p. 829119.

Jekosch, U. (2004), "Basic concepts and terms of quality, reconsidered in the context of product-sound quality", Acta Acustica United with Acustica, Vol. 90 No. 6, pp. 999-1006.

Jensen, K.B. and Helles, R. (2007), "The silent web. a qualitative study of sound as information and

Non-musical sound branding communication in websites", in Consalvo, M. and Haythornthwaite, C. (Eds), Internet Research Annual, Peter Lang, New York, NY, pp. 183-194.

Jessen, I. and Graakjær, N.J. (2009), "Functions of sound in web advertising", in Graakjær, N.J. and Jantzen, C. (Eds), Music in Advertising: Commercial Sounds in Media Communication and Other Settings, Aalborg University Press, Aalborg, pp. 195-221.

Kassabian, A. (2017), "Roundtable: current perspectives on music, sound, and narrative in screen media", in Mera, M., Sadoff, R. and Winters, B. (Eds), The Routledge Companion to Screen Music and Sound, Routledge, New York, NY, pp. 108-124.

Kellaris, J.J. (2008), "Music and consumers", in Haugtvedt, C.P., Herr, P.M. and Kardes, F.R. (Eds), Handbook of Consumer Psychology, Lawrence Erlbaum, New York, NY, pp. 837-856.

Kilian, K. (2009), "From brand identity to audio branding", in Bronner, K. and Hirt, R. (Eds), Audio Branding: Brands, Sound and Communication, Nomos, Baden-Baden, pp. 35-48.

Klink, R.R. and Wu, L. (2014), "The role of position, type, and combination of sound symbolism imbeds in Brand names", Marketing Letters, Vol. 25 No. 1, pp. 13-24.

Knöferle, K. (2012), "Using customer insights to improve product sound design”, Marketing Review St. Gallen, Vol. 29 No. 2, pp. 47-53.

Knöferle, K., Knoeferle, P., Velasco, C. and Spence, C. (2016), "Multisensory Brand search: how the meaning of sound guides consumers' visual attention", Advances in Consumer Research, Vol. 42, pp. 552-553.

Kotler, P. (1973), “Atmospherics as a marketing tool”, Journal of Retailing, Vol. 49 No. 4, pp. 48-64.

Krauss, F. (2010), Audio-Branding: Akustische Markenführung Als Strategische Säule Erfolgreicher Markenkommunikation, VDM Publishing, Saarbrücken.

Krishnan, V., Kellaris, J.J. and Aurand, T.W. (2012), "Sonic logos: can sound influence willingness to pay?", Journal of Product \& Brand Management, Vol. 21 No. 4, pp. 275-284.

Kuwano, S., Fastl, H., Namba, S., Nakamura, S. and Uchida, H. (2006), "Quality of door sounds of passenger cars", Acoustical Science and Technology, Vol. 27 No. 5, pp. 309-312.

LaBarbera, P. and MacLachlan, J. (1979), "Time-compressed speech in radio advertising”, Journal of Marketing, Vol. 43 No. 1, pp. 30-36.

Lafferty, D. (2015), "The power of sound in your practice", BDJ Team, Vol. 1, p. 15029.

Lageat, T., Czellar, S. and Laurent, G. (2003), "Engineering hedonic attributes to generate perceptions of luxury: consumer perception of an everyday sound", Marketing Letters, Vol. 14 No. 2, pp. 97-109.

Lalwani, A.K., Lwin, M. and Li, K.L. (2005), "Consumer responses to English accent variations in advertising”, Journal of Global Marketing, Vol. 18 Nos 3/4, pp. 143-165.

Langeveld, L., van Egmond, R., Jansen, R. and O«zcan, E. (2013), "Product sound design: intentional and consequential sounds", in Coelho, D.A. (Ed.), Advances in Industrial Design Engineering, InTech, Rijeka, pp. 47-74.

Lehmann, M. (2007), "Die stimme im markenklang”, in Bronner, K. and Hirt, R. (Eds), Audio-Branding: Entwicklung, Anwendung, Wirkung Akustischer Identitäten in Werbung, Medien Und Gesellschaft, Reinhard Fischer, Munich, pp. 97-101. 
Lehmann, M. (2008), Voice Branding: Die Stimme in Der Markenkommunikation, Reinhard Fischer, Munich.

Lindstrom, M. (2005), Brand Sense: How to Build Powerful Brands through Touch, Taste, Smell, Sight \& Sound, Free Press, New York, NY.

Lowe, M.L. and Haws, K.L. (2017), "Sounds big: the effects of acoustic pitch on product perceptions", Journal of Marketing Research, Vol. 54 No. 2, pp. 331-346.

Ludden, G.D. and Schifferstein, H.N. (2007), "Effects of visual-auditory incongruity on product expression and surprise", International Journal of Design, Vol. 1 No. 3, pp. 29-39.

Luna, D., Carnevale, M. and Lerman, D. (2009), "Herer is the thing: the influence of sound-to-writing correspondence on brand name processing”, ACR North American Advances, Vol. 36, pp. 965-966.

Luna, D., Carnevale, M. and Lerman, D. (2010), "Google or googol? How meanings of sound and spelling processes influence evaluations for Brand names", ACR North American Advances, Vol. 37, p. 860.

Luna, D., Carnevale, M. and Lerman, D. (2013), "Does Brand spelling influence memory? the case of auditorily presented Brand names", Journal of Consumer Psychology, Vol. 23 No. 1, pp. 36-48.

Lyon, R.H. (2003), "Product sound quality-from perception to design", Sound and Vibration, Vol. 37 No. 3, pp. 18-23.

MacLachlan, J. and Siegel, M.H. (1980), "Reducing the costs of TV commercials by use of time compressions", Journal of Marketing Research, Vol. 17 No. 1, pp. 52-57.

Miller, D.W. and Marks, L.J. (1992), "Mental imagery and sound effects in radio commercials", Journal of Advertising, Vol. 21 No. 4, pp. 83-93.

Moore, D.L., Hausknecht, D. and Thamodaran, K. (1986), "Time compression, response opportunity, and persuasion", Journal of Consumer Research, Vol. 13 No. 1, pp. 85-99.

Morales, A.C., Scott, M.L. and Yorkston, E.A. (2012), "The role of accent standardness in message preference and recall", Journal of Advertising, Vol. 41 No. 1, pp. 33-46.

Muela-Molina, C. and Perelló-Oliver, S. (2013), "Misleading advertising: a study of radio spots in Spain", Convergencia, Vol. 20 No. 62, pp. 13-43.

Murray, S. (2015), “The radio made betty”, Feminist Media Histories, Vol. 1 No. 4, pp. 46-70.

North, A.C., Mackenzie, L.C., Law, R.M. and Hargreaves, D.J. (2004), "The effects of musical and voice fit on responses to advertisements", Journal of Applied Social Psychology, Vol. 34 No. 8, pp. $1675-1708$.

Oakes, S. (2000), "The influence of the musicscape within service environments", Journal of Services Marketing, Vol. 14 No. 7, pp. 539-556.

Oakes, S. (2007), "Evaluating empirical research into music in advertising: a congruity perspective", Journal of Advertising Research, Vol. 47 No. 1, pp. 38-50.

Olsen, D. (1994), "Observations: the sounds of silence: functions and use of silence in television advertising", Journal of Advertising Research, Vol. 34 No. 5, pp. 89-96.

Olsen, G.D. (1995), "Creating the contrast: the influence of silence and background music on recall and attribute importance", Journal of Advertising, Vol. 24 No. 4, pp. 29-44.

Olsen, G.D. (1997), "The impact of interstimulus interval and background silence on recall”, Journal of Consumer Research, Vol. 23 No. 4, pp. 295-303.

Olson, J.C. and Dover, P.A. (1978), "Cognitive effects of deceptive advertising”, Journal of Marketing Research, Vol. 15 No. 1, pp. 29-38.

Özcan, E. (2014), "The Harley effect: internal and external factors that facilitate positive experiences with product sounds", Journal of Sonic Studies, Vol. 6 No. 1, pp. 1-16.

Ozcan, E. and Schifferstein, H.N.J. (2014), "The effect of (un)pleasant sounds on the visual and overall pleasantness of products”, in Salamanca, J., Desmet, P., Burbano, A., Ludden, G. and Maya, J. 
(Eds), Proceedings of the colors of care: the 9th international conference on design and emotion, Ediciones Uniandes, Bogota, pp. 601-606.

Özcan, E. and van Egmond, R. (2007), "Memory for product sounds: the effect of sound and label type", Acta Psychologica, Vol. 126 No. 3, pp. 196-215.

Özcan, E. and van Egmond, R. (2009), "The effect of visual context on the identification of ambiguous environmental sounds", Acta Psychologica, Vol. 131 No. 2, pp. 110-119.

Özcan, E. and van Egmond, R. (2012), "Basic semantics of product sounds", International Journal of Design, Vol. 6 No. 2, pp. 41-54.

Pan, Y. and Schmitt, B. (1996), "Language and brand attitudes: impact of script and sound matching in Chinese and English”, Journal of Consumer Psychology, Vol. 5 No. 3, pp. 263-277.

Pasnau, R. (1999), "What is sound?”, The Philosophical Quarterly, Vol. 49 No. 196, pp. 309-324.

Peck, J., Childers, T.L. (2008), "Effects of sensory factors in consumer behavior: if it tastes, smells, sounds, and feels like a duck, then it must be a . ..”, in Haugtvedt, C.P., Herr, P. and Kardes, F.R. (Eds), Handbook of Consumer Psychology, Lawrence Erlbaum, New York, NY, pp. 193-219.

Peterson, R.A., Cannito, M.P. and Brown, S.P. (1995), "An exploratory investigation of voice characteristics and selling effectiveness", Journal of Personal Selling \& Sales Management, Vol. 15 No. 1, pp. 1-15.

Petticrew, M. and Roberts, H. (2006), Systematic Reviews in the Social Sciences: A Practical Guide, Blackwell Pub., Malden.

Powers, D. (2010), "Strange powers: the branded sensorium and the intrigue of musical sound", in Aronczyk, M. and Powers, D. (Eds), Blowing up the Brand: Critical Perspectives on Promotional Culture, Peter Lang, New York, NY, pp. 285-306.

Raffaseder, H. (2007), "Klangmarken und markenklänge: die bedeutung der klangfarbe im audio-branding”, in Bronner, K. and Hirt, R. (Eds), Audio Branding: Entwicklung, Anwendung, Wirkung Akustischer Identitäten in Werbung, Medien Und Gesellschaft, Reinhard Fischer, München, pp. 102-117.

Reece, B.B., van den Bergh, B.G. and Li, H. (1994), "What makes a slogan memorable and who remembers it", Journal of Current Issues \& Research in Advertising, Vol. 16 No. 2, pp. 41-57.

Rehan, R.M. (2016), "The phonic identity of the city urban soundscape for sustainable spaces”, HBRC Journal, Vol. 12 No. 3, pp. 337-349.

Rodero, E., Larrea, O., Mas, L., Vázquez, M. and Blanco, M. (2015), "When the internet seems to be deaf. Sound resources to enrich online radio advertising", Net station conference proceedings: radio, sound and internet, 2015, Braga, pp. 362-372.

Rotfeld, H.J. and Rotzoll, K.B. (1980), "Is advertising puffery believed?", Journal of Advertising, Vol. 9 No. 3, pp. 16-45.

Sapherstein, M.P. (1998), “The trademark registrability of theHarleyyDavidsonn roar: a multimedia analysis". Boston College Intellectual Property \& Technology Forum, available at: http://bciptf.org/ wp-content/uploads/2011/07/48-THE-TRADEMARK-REGISTRABILITY-OF-THE-HARLEY.pdf (accessed 26 August 2017).

Sayin, E., Krishna, A., Ardelet, C., Decré, G.B. and Goudey, A. (2015), "Sound and safe": the effect of ambient sound on the perceived safety of public spaces", International Journal of Research in Marketing, Vol. 32 No. 4, pp. 343-353.

Schlinger, M.J.R., Alwitt, L.F., McCarthy, K.E. and Green, L. (1983), "Effects of time compression on attitudes and information processing", Journal of Marketing, Vol. 47 No. 1, pp. 79-85.

Schutz, H.G. and Casey, M. (1981), "Consumer perceptions of advertising as misleading”, Journal of Consumer Affairs, Vol. 15 No. 2, pp. 340-357.

Shevy, M. and Hung, K. (2013), "Music in television advertising and other persuasive media", in Tan, S. L., Cohen, A.J., Lipscomb, S.D. and Kendall, R.A. (Eds), The Psychology of Music in Multimedia, Oxford University Press, Oxford, pp. 315-334.
Non-musical sound branding 
$\mathrm{EJM}$

$52,7 / 8$

Shingler, M. and Wieringa, C. (1998), On Air: Methods and Meanings of Radio, Arnold Publishers, London.

Spence, C. (2011), "Sound design: using brain science to enhance auditory and multisensory product and brand development", in Bronner, K., Hirt, R. and Ringe, C. (Eds), Audio Branding Academy Yearbook 2010/2011, Nomos/Reinhard Fischer, Baden-Baden, pp. 35-52.

Spence, C. (2012), "Auditory contributions to flavour perception and feeding behaviour", Physiology \& Behavior, Vol. 107 No. 4, pp. 505-515.

Spence, C. (2014), "Noise and its impact on the perception of food and drink", Flavour, Vol. 3 No. 1, p. 9.

Spence, C. (2015), "Eating with our ears: assessing the importance of the sounds of consumption on our perception and enjoyment of multisensory flavour experiences", Flavour, Vol. 4 No. 1, p. 3.

Spence, C. and Wang, Q. (2015), "Sensory expectations elicited by the sounds of opening the packaging and pouring a beverage", Flavour, Vol. 4 No. 1, p. 35.

Spence, C. and Zampini, M. (2006), "Auditory contributions to multisensory product perception", Acta Acustica United with Acustica, Vol. 92 No. 6, pp. 1009-1025.

Spence, C. and Zampini, M. (2007), "Affective design: modulating the pleasantness and forcefulness of aerosol sprays by manipulating aerosol spraying sounds", CoDesign, Vol. 3 No. 1, pp. 107-121.

Spence, C., Puccinelli, N.M., Grewal, D. and Roggeveen, A.L. (2014), "Store atmospherics: a multisensory perspective", Psychology \& Marketing, Vol. 31 No. 7, pp. 472-488.

Susini, P., Houix, O. and Misdariis, N. (2014), "Sound design: an applied, experimental framework to study the perception of everyday sounds", The New Soundtrack, Vol. 4 No. 2, pp. 103-121.

Susini, P., McAdams, S., Winsberg, S., Perry, I., Vieillard, S. and Rodet, X. (2004), "Characterizing the sound quality of air-conditioning noise”, Applied Acoustics, Vol. 65 No. 8, pp. 763-790.

Tagg, P. (2013), Music's Meanings: A Modern Musicology for Non-Musos, Mass Media Music Scholars' Press, New York, NY.

Tonetto, L.M. and Trevisan, R.B.L. (2012), Testingg affective responses to different brand vocal and sound logo stimuli: a case study", in Bronner, K. and Hirt, R. (Eds), Audio Branding Academy Yearbook 2011/2012, Nomos, Baden-Baden, pp. 141-149.

Truax, B. (2001), Acoustic Communication, Ablex, Westport, CT.

Tsang, L. (2007), "Sound and music in website design", in Sexton, J. (Ed.), Music, Sound and Multimedia: From the Live to the Virtual, Edinburgh University Press, Edinburgh, pp. 145-171.

Turley, L.W. and Milliman, R.E. (2000), "Atmospheric effects on shopping behavior", Journal of Business Research, Vol. 49 No. 2, pp. 193-211.

Underwood, R.L. (2003), "The communicative power of product packaging: creating Brand identity via lived and mediated experience", Journal of Marketing Theory and Practice, Vol. 11 No. 1, pp. 62-76.

van Egmond, R. (2008), "Impact of sound on image-evoked emotions", in Rogowitz, B.E. and Pappas, T. N. (Eds), Human Vision and Electronic Imaging XIII, Proceedings of SPIE-IS\&T Electronic Imagining, p. 6806.

van Leeuwen, T. (1999), Speech, Music, Sound, Macmillan Education, London.

Västfjäll, D., Gulbol, M.A., Kleiner, M. and Gärling, T. (2002), "Affective evaluations of and reactions to exterior and interior vehicle auditory quality", Journal of Sound and Vibration, Vol. 255 No. 3, pp. $501-518$.

Västfjäll, D., Kleiner, M. and Gärling, T. (2003), “Affective reactions to interior aircraft sounds”, Acta Acustica United with Acustica, Vol. 89 No. 4, pp. 693-701.

Wagner, V. and Kallus, W. (2015), "Sound quality of turn indicator sounds - use of a multidimensional approach in the automotive product development", Journal of Traffic and Transportation Engineering, Vol. 3, pp. 158-165. 
Westermann, C.F. (2008), "Sound branding and corporate voice - strategic brand management using sound", in Hempel, T. (Ed.), Usability of Speech Dialog Systems: Listening to the Target Audience, Springer, Berlin, Heidelberg, pp. 147-155.

Yoon, J.H., Yang, I.H., Jeong, J.E., Park, S.G. and Oh, J.E. (2012), "Reliability improvement of a sound quality index for a vehicle HVAC system using a regression and neural network model", Applied Acoustics, Vol. 73 No. 11, pp. 1099-1103.

Yorkston, E. (2010), "Auxiliary auditory ambitions:assessingg ancillary and ambient sounds", in Krishna, A. (Ed.), Sensory Marketing: Research on the Sensuality of Products, Routledge, New York, NY, pp. 157-167.

Zampini, M. and Spence, C. (2004), "The role of auditory cues in modulating the perceived crispness and staleness of potato chips", Journal of Sensory Studies, Vol. 19 No. 5, pp. 347-363.

Zampini, M. and Spence, C. (2005), "Modifying the multisensory perception of a carbonated beverage using auditory cues", Food Quality and Preference, Vol. 16 No. 7, pp. 632-641.

Zampini, M., Guest, S. and Spence, C. (2003), "The role of auditory cues in modulating the perception of electric toothbrushes", Journal of Dental Research, Vol. 82 No. 11, pp. 929-932.

\section{Corresponding author}

Nicolai Jørgensgaard Graakjær can be contacted at: nicolaig@hum.aau.dk

For instructions on how to order reprints of this article, please visit our website: 